\title{
Possibilities of developing Favourable Body Fat Partition Via Selection Indexes - Application on Rabbits
}

\begin{abstract}
Summary
Estimates of phenotypic and genetic parameters of body fat partition and other related traits were calculated using an experimental material of 152 New Zealand White rabbits of 15 bucks and 42 adult does. To construct nine selection indexes aiming at improving fat partition, estimates of phenotypic and genetic parameters for weight and linear dimensions of the live body were also obtained. The aggregate genotype included the percentage total body fat depositing subcutaneously and intermuscularly at the marketing age of 12 weeks. The full index included the weaning body weight, marketing body weight, body length, loin width and heart girth.

The full index had the highest correlation with the true breeding value $\left(\mathrm{r}_{\mathrm{TI}}=0.597\right)$. Comparable accuracy $\left(\mathrm{r}_{\mathrm{TI}}=\right.$ 0.561 ) would be expected from the best-reduced index $\left(\mathrm{I}_{7}=0.009 \mathrm{BW}-0.988 \mathrm{HG}\right)$ combining marketing body weight and heart girth. At each round of selection with intensity $=1$, such a reduced index is expected to result in developing rabbits with advantageous fat partition in terms of higher percentage total body fat depositing subcutaneously ( +0.35 unit \%), intermuscularly $(+1.91$ unit $\%)$ and intramuscularly (as reflected by 0.15 unit $\%$ increase in carcass muscle yield.

As compared with its unrestricted form, the best reduced index reduced to zero change in total body fat $\left(\mathrm{I}_{7(\mathrm{TBF})}\right)$ would result in drastic decline in percentage total fat depositing as kidney knob and channel fat ( +0.32 vs. -0.18 unit \%) with little amelioration in percentage total fat accumulating in the other depots. Selection on $\mathrm{I}_{7(\mathrm{TBF})}$ instead of $\mathrm{l}_{7}$ would reduce improvement in marketing body weight $(+0.52 \mathrm{vs} .+0.33 \mathrm{gm})$, carcass yield $(+0.10 \mathrm{vs}$. 0.04 unit \%) and carcass boneless meat yield (+0.19 vs. 0.07 unit \%) with increase of gain in carcass muscle yield ( +0.15 vs. 0.32 unit $\%)$.
\end{abstract}

Key Words: Body fat partition, genetic parameters, selection indexes, New Zealand White rabbits

\section{Zusammenfassung}

Titel der Arbeit: Beeinflussung der K.̈rperfettverteilung mittels Selektionsindizes bei Kaninchen der Rasse Weiße Neuseeländer

Phănotypische und genetische Parameter wurden an 152 Tieren der Rasse Weiße Neuseelănder, die im Alter von 12 Wochen geschlachtet wurden, geschätzt. Einbezogen waren verschiedene Körperfett- und weitere Schlachtmerkmale, die für die Konstruktion von Selektionsindizes bei unterschiedlicher Merkmalswichtung, genutzt wurden. Besonderes Augenmerk galt der Reduzierung von Gesamtfettgehalt sowie des subcutanen und intramuskulären Fettanteils. Die Selektionswirkungen der einzelnen Indexvarianten mit oder ohne Restriktion werden dargestellt und diskutiert Es konnte nachgewiesen werden, daß durch die Wahl bestimmter Indexvarianten eine selektive Beeinflussung der Schlachtkörper in Richtung höherer Marktqualităt erreicht werden kann.

Schlüsselwörter: Körperfettverteilung, genetische Parameter, Selektionsindizes, Kaninchen, Weiße Neuseeländer

\section{Introduction}

Body fat partition influences the weight and acceptability of the carcass in that a gram of total body fat deposited as carcass fat (subcutaneously, intermuscularly or intramuscularly) is normally of much greater value than the same amount of total body 
fat accumulated as non-carcass fat (heart, caul, mesenteric or kidney knob and channel) depots.

Types of body fat partition have been identified for dairy cattle (e.g. TRUSCOTT et al., 1976; BUTLER-HOGG and WOOD, 19.82), beef cattle (e.g. SHAHIN and BERG, 1985), beef $x$ dairy crossbreds (e.g. KEMPSTER et al., 1976), water buffaloes (e.g. ABDALLAH et al., 1982), sheep (e.g. KEMPSTER, 1981; JONES, 1982); pigs (e.g. JONES et al., 1980) and broilers (e.g. GRIFFITHS et al., 1978; MERKLEY et al., 1980; SHAHIN et al., 1990). However, there is no available information on the genetics of fat partitioning so as to modify it to the profit of meat producers.

The aim of the present study was to investigate the possibilities of developing favourable body fat partition via selection indexes using dissection data on rabbits. With use of such a relatively lean species, it would be possible to develop selection indexes (S.I.) for animals with sub-optimal levels of fatness (unrestricted S.I.) as well as for those attaining optimal fatness (restricted S.I.).

\section{Material and Methods}

Source of Data. Over two successive parities during the spring of 1997, forty-two adult New Zealand White does were inseminated with fresh semen collected from fifteen bucks of the same breed at the experimental rabbitry of the Faculty of Agriculture, Ain Shams University, Egypt. From these matings one hundred and fifty two weaned male progeny were used in the present analyses.

Rearing of Animals. Following their birth, the experimental rabbits remained with their dams in breeding batteries till weaning at four weeks of age. They were then ear tagged and transferred to fattening batteries where fed ad libitum commercial pelleted diet (SHEMEIS and ABDALLAH, 1998) containing $16.3 \%$ crude protein, $14.0 \%$ crude fiber, $2.5 \%$ crude fat and providing $2670 \mathrm{~K}$. cal. digestible energy $/ \mathrm{kg}$. diet through to marketing at twelve weeks of age.

At marketing age, the animals were weighed and their body length, loin width and heart girth were measured (LUKEFAHR and OZIMBA, 1991). They were slaughtered and dressed with the heart, mesenteric, caul and kidney knob and channel fats being removed and weighed. The carcasses were weighed and held at $2{ }^{\circ} \mathrm{C}$ for 24 hours before subcutaneous fat (SCF), intermuscular fat (IMF) and muscles of the right sides were dissected. The weights of SCF and IMF were multiplied by two and added (1) to weights of the non-carcass fat depots to give total body fat and (2) to twice the dissected side muscle weight to give the carcass boneless meat weight.

Statistical Model of Analysis. The genetic and phenotypic parameters of the traits describing body weights and dimensions, total body fat partition and carcass attributes were estimated using the Least Squares and Maximum Likelihood program of HARVEY (1990) according to the following mixed model:

where:

$$
\mathbf{Y}_{i j k l}=\mathbf{u}+\mathbf{S}_{\mathrm{i}}+\mathbf{D}_{\mathrm{ij}}+\mathbf{P}_{\mathrm{k}}+\mathbf{e}_{\mathrm{ijkl}}
$$

\footnotetext{
$Y_{i j k l}=$ The observation of the $\mathrm{l}^{\text {th }}$ rabbit of the $\mathrm{k}^{\text {th }}$ parity from the $\mathrm{j}^{\text {th }}$ dam and the $i^{\text {th }}$ buck;

$\mathrm{u}=$ The overall mean;
} 
$\mathrm{S}_{\mathrm{i}} \quad=$ The random effect of the $\mathrm{i}^{\text {th }}$ buck $(\mathrm{i}=1,2, \ldots, 15)$;

$D_{i j}=$ The random effect of the $j^{\text {th }}$ dam $(j=1,2, \ldots, 42)$ nested within the $i^{\text {th }}$ buck;

$P_{k}=$ The fixed effect of the $k^{\text {th }}$ parity $(k=1,2)$; and

$\mathrm{e}_{\mathrm{ijkl}}=$ The random error assumed N.I.D. $\left(0, \sigma_{\mathrm{e}}^{2}\right)$.

The net income in the present study was defined as the revenue realised by the meat producer in terms of the added value to the carcass weight through the proportionate increase in deposition of total body fat as subcutaneous and intermuscular fats.

The true breeding value $(\mathrm{T})$ was then defined as:

where:

$$
\mathrm{T}=\mathrm{a}_{1} \mathrm{~g} \mathrm{SCF}_{\mathrm{SC}}+\mathrm{a}_{2} \mathrm{~g}_{\mathrm{IMF}}
$$

$\mathrm{g} \mathrm{SCF}_{\text {SC }}$ The additive genetic value for subcutaneous fat measured as percentage of total body fat;

$\mathrm{g}_{\mathrm{IMF}}=$ The additive genetic value for intermuscular fat measured as percentage of total body fat; and

$a_{1}$ and $a_{2}=$ The relative economic weights for SCF and IMF as percentage of total body fat, respectively.

An economic value that equals to unity was assigned to both traits, since a unit \% of total body fat depositing as either SCF or IMF would equally contribute to the net profit of meat producer.

Sources of information (weaning weight; marketing body weight, body length, loin width and heart girth) were used in different combinations to construct nine selection indexes (CUNNINGHAM et al., 1970) out of which two were developed by imposing restriction on total body fat weight.

\section{Results and Discussion}

Phenotypic variation. Coefficients of phenotypic variation for the variables studied are given in Table 1.

Much larger amount of phenotypic variation was observed for the percentage total body fat depositing viscerally (30.2 to $38.7 \%$ ) and subcutaneously $(30.4 \%)$ than for that occurring intermuscularly (13.8\%). In the works of KEMPSTER et al.(1976) and SHAHIN and BERG (1985) on beef cattle, the phenotypic variation for the proportionate total body fat accumulating around the kidneys was much higher than for that deposited between muscles.

Slaughter traits showed low and comparable amounts of phenotypic variation $\quad(4.3 \%$ for carcass yield; $3.2 \%$ for carcass muscle yield and $3.1 \%$ for carcass boneless meat yield).

Phenotypic variation in body weight decline from weaning to marketing (difference of $9.8 \%)$. At marketing, the variation in the weight of the body (11.8\%) was considerably much lower than in the weight of its total fat $(50.3 \%)$.

Heritabilities. Heritability estimates $\left(\mathrm{h}^{2}\right)$ based on paternal half sib variance components for the traits considered in the study are also given in Table 1. Generally, body fat partition and slaughter traits were less heritable than live body measurements. 
Heritability had low estimates $(0.131$ to 0.150$)$ for intermuscular fat, mesenteric fat and caul fat, medium estimates for subcutaneous fat (0.266) and heart fat (0.329) and a high estimate ( 0.787$)$ for kidney knob and channel fat.

Table 1

Mean $(\bar{x})$, Phenotypic Coefficient of Variation (C.V. \%) and Heritability Coefficient $\left(\mathrm{h}^{2}\right)( \pm$ Standard

Error) for Total Body Fat Partition, Related Slaughter Traits and Live Body Measurements (Mittelwerte, Variationskoeffizienten und Heritabilitătswerte untersuchter Korper- und Schlachtmerkmale)

\begin{tabular}{|c|c|c|c|}
\hline Parameter & $\bar{x}$ & C.V. \% & $h^{2} \pm S E$ \\
\hline \multicolumn{4}{|l|}{ i. Body fat partition traits ${ }^{I}$} \\
\hline \multicolumn{4}{|l|}{ Percentage total body fat depositing as: } \\
\hline Heart fat & 8.33 & 36.62 & $0.329 \pm 0.200$ \\
\hline Mesentric fat & 16.69 & 30.16 & $0.150 \pm 0.094$ \\
\hline Caul fat & 5.36 & 30.58 & $0.139 \pm 0.046$ \\
\hline Kidney knob and channel fat & 17.17 & 38.72 & $0.787 \pm 0.198$ \\
\hline Carcass subcutaneous fat & 20.00 & 30.40 & $0.266 \pm 0.188$ \\
\hline Carcass intermuscular fat & 32.45 & 13.78 & $0.131 \pm 0.015$ \\
\hline \multicolumn{4}{|l|}{ ii. Related slaughter traits } \\
\hline Total body fat, gm & 69.70 & 49.61 & $0.803 \pm 0.193$ \\
\hline Carcass yield ${ }^{2}, \%$ & 48.80 & 4.28 & $0.193 \pm 0.125$ \\
\hline Carcass boneless meat yield ${ }^{3}, \%$ & 85.09 & 3.08 & $0.329 \pm 0.191$ \\
\hline Carcass muscle yield ${ }^{4}, \%$ & 80.24 & 9.47 & $0.219 \pm 0.151$ \\
\hline \multicolumn{4}{|l|}{ iii. Live body measurements } \\
\hline Weaning body weight, gm & 425 & 21.65 & $0.631 \pm 0.187$ \\
\hline Marketing body weight, gm & 1895 & 11.82 & $0.820 \pm 0.225$ \\
\hline Marketing body length, $\mathrm{cm}$ & 31.0 & 5.00 & $0.145 \pm 0.111$ \\
\hline Marketing loin width, $\mathrm{cm}$ & 6.0 & 15.00 & $0.593 \pm 0.226$ \\
\hline Marketing heart girth, $\mathrm{cm}$ & 23.4 & 7.69 & $0.773 \pm 0.202$ \\
\hline $\begin{array}{l}\text { (1) Fat depot weight relative to total } \\
\text { (2) Hot carcass weight relative to ma } \\
\text { (3) Twice side boneless meat weight } \\
\text { (4) Twice side muscle weight relative }\end{array}$ & e weight. & & \\
\hline
\end{tabular}

The low heritability estimates for carcass yield $(0.193$, Table $1 ; 0.22$, MAHAJAN and LAHIRI, 1983) and carcass muscle yield $(0.219$, Table $1 ; 0.16$ and 0.19 , GEBRIEL et al., 1989) justify the need for indirect selection for improving these traits.

The $h^{2}$-value of 0.82 for marketing body weight of New Zealand White rabbits estimated in the present study is higher than those previously obtained on the same breed (0.54, CARREGAL et al.,1980; 0.22, NIEDZWIADEK, 1978; 0.29, MAHAJAN and LAHIRI, 1983; 0.29, KROGMEIER et al., 1994). The $\mathrm{h}^{2}$ estimates for weaning

\section{Legends to Tables 2 and 3 (see page 197)}

Table 2

Genetic (Above Diagonal) and Phenotypic (Below Diagonal) Correlations Among Total Body Fat Partition Traits, and Related Slaughter Traits and Live Body Measurements (Genetische (oberhalb Diagonale) und phänotypische Korrelationen zwischen Fettgehalts- und anderen untersuchten Merkmalen)

Table 3

Weighing Factors, Standard Deviation, Accuracy of Selection and Relative Efficiency Estimated for Each Index Without and with Restriction on Total Body Fat Weight (TBF) (Wichtungsfaktoren, Standardabweichung, Genauigkeit und Effizienz verglichener Indexvarianten) 
i. Total body fat partition traits

Percentage total body fat depositing

$v_{1}$ Heart fat

$V_{2}$ Mesenteric fat

$V_{3}$ Caul fat

$V_{4}$ Kidney knob and channel fat

$V_{s}$ Subcutaneous fat

ii. Related slaughter traits

$\mathrm{V}_{7}$ Total body fat weight, gm

$\mathrm{V}_{\mathrm{z}}$ Carcass yield ${ }^{2}, \%$

V, Carcass boneless meat yield ${ }^{3}, \%$

$\mathrm{V}_{\text {to }}$ Carcass muscle yield", $\%$

iii. Live body measurements

$\mathrm{V}_{\mathrm{u}}$ Weaning weight

$V_{11}$ Weaning weight
$V_{12}$ Marketing body weight

$V_{12}$ Marketing body weight

$\mathrm{V}_{14}$ Mrketing

$V_{15}$ Marketing heart girth

$\begin{array}{cccccc}\ldots . . & 0.52 & 0.72 & -0.92 & -0.35 & 0.24 \\ 0.13 & \ldots . . & 0.59 & -0.91 & 0.08 & 0.38 \\ -0.04 & 0.10 & \ldots . . & 0.14 & -0.12 & 0.40 \\ -0.58 & -0.20 & 0.16 & \ldots . . & -0.10 & -0.30 \\ -0.21 & 0.08 & -0.02 & -0.12 & \ldots . . & 0.35 \\ 0.21 & 0.05 & -0.15 & -0.45 & -0.22 & \ldots . \\ & & & & & \\ -0.61 & -0.21 & 0.15 & 0.88 & 0.02 & -0.34 \\ -0.39 & -0.20 & 0.29 & 0.03 & 0.15 & -0.20 \\ -0.22 & -0.30 & 0.30 & -0.01 & 0.19 & -0.25 \\ 0.69 & 0.20 & 0.04 & -0.52 & -0.07 & -0.71 \\ & & & & & \\ -0.01 & -0.06 & -0.03 & -0.05 & 0.06 & -0.12 \\ -0.46 & -0.23 & 0.15 & 0.80 & -0.01 & -0.37 \\ -0.07 & -0.02 & 0.08 & 0.34 & 0.01 & -0.20 \\ -0.46 & -0.24 & 0.11 & 0.69 & -0.01 & -0.28 \\ -0.49 & -0.19 & 0.15 & 0.81 & -0.02 & -0.34\end{array}$

ii. Related slaughter traits

iii. live body measurements

\begin{tabular}{llll}
\hline $\mathrm{V}$, & $\mathrm{V}_{3}$ & $\mathrm{~V}_{9}$ & $\mathrm{~V}_{10}$
\end{tabular}

\begin{tabular}{lllll}
\hline $\mathrm{V}_{11}$ & $\mathrm{~V}_{12}$ & $\mathrm{~V}_{13}$ & $\mathrm{~V}_{14}$ & $\mathrm{~V}_{15}$
\end{tabular}

Table 3

\begin{tabular}{|c|c|c|c|c|c|c|c|c|}
\hline \multirow[b]{3}{*}{ Index } & \multicolumn{8}{|c|}{ Estimates obtained in constructing indexes } \\
\hline & \multicolumn{5}{|c|}{ Weighing factors for: } & \multirow[b]{2}{*}{$\begin{array}{l}\text { Standard } \\
\text { deviation }\end{array}$} & \multirow[b]{2}{*}{$\begin{array}{l}\text { Accuracy of } \\
\text { selection }\end{array}$} & \multirow[b]{2}{*}{$\begin{array}{l}\text { Relative } \\
\text { efficiency }\end{array}$} \\
\hline & $\begin{array}{l}\text { Weaning } \\
\text { weight }\end{array}$ & $\begin{array}{l}\text { Marketing } \\
\text { body weight }\end{array}$ & $\begin{array}{l}\text { Marketing } \\
\text { body length }\end{array}$ & $\begin{array}{l}\text { Marketing } \\
\text { loin width }\end{array}$ & $\begin{array}{l}\text { Marketing } \\
\text { heart girth }\end{array}$ & & & \\
\hline \multicolumn{9}{|c|}{$\begin{array}{l}\text { Without restriction on total } \\
\text { body fat weight }\end{array}$} \\
\hline$I_{1}$ (full index) & -0.005 & 0.010 & -0.138 & -1.186 & -0.513 & 5.762 & 0.597 & 100 \\
\hline $\mathrm{I}_{2}$ & -0.005 & 0.006 & ...... & ...... & ...... & 2.395 & 0.395 & 66 \\
\hline $\mathrm{l}_{3}$ & ...... & 0.007 & ...... & & & 2.186 & 0.368 & 62 \\
\hline $\mathrm{L}$ & ...... & ...... & 0.301 & -0.488 & -0.556 & 1.662 & 0.321 & 54 \\
\hline$I_{s}$ & ...... & ...... & ...... & -1.200 & & 1.186 & 0.271 & 45 \\
\hline $\mathrm{I}_{6}$ & ...... & ...... & ...... & ...... & -0.667 & 1.440 & 0.298 & so \\
\hline \multirow{2}{*}{\multicolumn{9}{|c|}{$\begin{array}{l}\text { With restriction on total body } \\
\text { fat weight }\end{array}$}} \\
\hline & & & & & & & & \\
\hline $\mathrm{I}_{1}$ (TR) & -0.004 & 0.009 & -0.083 & -1.148 & -0.651 & 5.646 & 0.591 & 99 \\
\hline 17 С० & $\ldots \ldots$ & 0.008 & $\ldots \ldots$ & $\ldots \ldots$ & -1.058 & 5.041 & 0.558 & 93 \\
\hline
\end{tabular}


weight of $0.63,0.55$ and 0.51 obtained in the present study and in the works of OUHAYOUN et al.(1973) and MERKUSHIN (1979), respectively, are well above the estimates of 0.10 and 0.20 obtained by EL-AMIN (1974) and CHEVALET (1976), respectively.

As for body dimensions, the heart girth was the most heritable trait $(0.773)$ followed by loin width $(0.593)$ then body length $(0.145)$.

Correlations. The genetic and phenotypic correlations among the traits considered in the study are given in Table 2.

Selection against excessively fat bodies would greatly decrease the percentage total body fat depositing as kidney knob and channel fat $\left(\mathrm{r}_{\mathrm{G}}=+0.79\right)$. This would be associated with increase in the percentage total body fat accumulating around the heart $\left(\mathrm{r}_{\mathrm{G}}=-0.92\right)$ and intestines $\left(\mathrm{r}_{\mathrm{G}}=-0.37\right)$ and subcutaneously $\left(\mathrm{r}_{\mathrm{G}}=-0.75\right)$. The genetic correlation between total body fat weight and its percentage occurring intermuscularly is negligible $\quad(-0.01)$, which indicates that in this material body fat weight in no way describes the genetic variation in its proportion depositing between muscles.

Genetic improvement of the percentage total body fat depositing as kidney knob and channel fat would seem to go along with improvement in carcass boneless meat yield $\left(\mathrm{r}_{\mathrm{G}}=+0.77\right)$ and carcass yield $\left(\mathrm{r}_{\mathrm{G}}=+0.33\right)$. Genetic correlations showed concomitant reduction in shares in total body fat would be expected at more drastic levels viscerally (around the heart, 0.91; and intestines, 0.92) than in the carcass (intermuscularly, -0.10 ; and subcutaneously, -0.30 )

Marketing body weight and dimensions are genetically correlated positively with total body fat weight $\left(\mathrm{r}_{\mathrm{G}}=0.68\right.$ to 0.98$)$ and its proportion depositing as kidney knob and channel fat $\left(\mathrm{r}_{\mathrm{G}}=0.82\right.$ to 0.94$)$, and genetically correlated negatively with percentage total body fat accumulating around the heart $\left(\mathrm{r}_{\mathrm{G}}=-0.69\right.$ to -0.91$)$ and intestines $\left(\mathrm{r}_{\mathrm{G}}=\right.$ -0.18 to -0.82 ). This relation expresses early maturity of large sized male rabbits of this breed.

In spite of the foregoing relationships, marketing body length and loin width are less useful than marketing body weight and its traditional estimator, the heart girth, to evaluate genetic differences in total body fat partition due to their lower $\mathrm{h}^{2}$ values.

Indexes. The estimates of genetic and phenotypic (co)variances and the relative economic values obtained in the present study were used to construct nine selection indexes .

Table 3 gives the weighing factors, standard deviation, accuracy of selection for each index together with the relative efficiency in relation to the full index.

Weighing factors were positive for marketing body weight and negative for marketing body dimensions due to their respectively high positive and negative genetic correlations with intermuscular fat.

The maximum accuracy of selection $\left(\mathrm{r}_{\mathrm{TI}}=0.597\right)$ was obtained using the full index $\left(\mathrm{I}_{1}\right)$. Whereas selection based on body weights $\left(\mathrm{I}_{2}\right.$ and $\left.\mathrm{I}_{3}\right)$ or body dimensions $\left(\mathrm{I}_{4}, \mathrm{I}_{5}\right.$ and $\mathrm{I}_{6}$ ) is expected to be of little effect in predicting the true breeding value considered in the present study ( $\mathrm{r}_{\mathrm{TI}}=0.368$ to 0.395 and 0.271 to 0.321 , respectively), selection on the best reduced index involving marketing body weight and heart girth $\left(\mathrm{I}_{7}\right)$ is expected to be $96 \%$ as efficient as the full index. Restricting the expected genetic change in total body fat weight to zero through use of $I_{1(\mathrm{TBF})}$ and $\mathrm{I}_{7(\mathrm{TBF})}$ would cause 
only one percent reduction in the accuracy of selection.

Table 4 gives results of the expected outcome for individual traits through use of the full index and the best reduced index in their original $\left(\mathrm{I}_{1}\right.$ and $\left.\mathrm{I}_{7}\right)$ and restricted forms $\left(\mathrm{I}_{\mathrm{l}(\mathrm{TBF})}\right.$ and $\left.\mathrm{I}_{7(\mathrm{TBF})}\right)$ using intensity of selection $=1.0$.

Table 4

The genetic changes per generation in total body fat partition characteristics, related slaughter traits and live body measurements expected from selection with intensity $=1.00$ using indexes with and without restriction on total body fat (TBF) (Selektionsfortschritt je Generation $(\mathrm{SI}=1.0)$ bei Körperfettmerkmalen und weiteren Körper- und Schlachtmerkmalen bei Selektionsindizes mit und ohne Restriktion)

\begin{tabular}{|c|c|c|c|c|c|}
\hline & \multicolumn{4}{|c|}{ Indexes* } & \multirow[b]{3}{*}{$\begin{array}{c}\text { Actual } \\
\text { mean }\end{array}$} \\
\hline & \multicolumn{2}{|c|}{$\begin{array}{c}\text { Without } \\
\text { restriction on total } \\
\text { body fat weight }\end{array}$} & \multicolumn{2}{|c|}{$\begin{array}{c}\text { With restriction } \\
\text { on total body fat } \\
\text { weight }\end{array}$} & \\
\hline & $\begin{array}{c}\mathrm{I}_{1} \\
\text { full } \\
\text { index }\end{array}$ & $\begin{array}{l}\mathrm{I}_{7} \\
\text { best } \\
\text { reduced } \\
\text { index }\end{array}$ & $\begin{array}{l}\mathrm{I}_{\text {(TBF) }} \\
\text { full } \\
\text { index }\end{array}$ & $\begin{array}{l}\mathrm{I}_{7(\mathrm{TBF})} \\
\text { best } \\
\text { reduced } \\
\text { index } \\
\end{array}$ & \\
\hline \multicolumn{6}{|l|}{ i. Total body fat partition traits } \\
\hline \multicolumn{6}{|l|}{$\begin{array}{l}\text { Percentage total body fat } \\
\text { depositing as: }\end{array}$} \\
\hline Heart fat & -0.08 & -0.09 & +0.15 & +0.05 & 8.33 \\
\hline Mesenteric fat & -0.53 & -0.27 & -0.26 & -0.10 & 16.69 \\
\hline Caul fat & +0.11 & +0.06 & +0.08 & +0.05 & 5.36 \\
\hline Kidney knob and channel fat & +0.78 & +0.37 & -0.10 & -0.18 & 17.17 \\
\hline Subcutaneous fat & +0.08 & +0.35 & +0.11 & +0.36 & 20.00 \\
\hline Intermuscular fat & +2.32 & +1.91 & +2.27 & +1.90 & 32.45 \\
\hline \multicolumn{6}{|l|}{ ii. Related slaughter traits } \\
\hline Total body fat, gm & +4.9 & +3.0 & 0.00 & 0.00 & 69.7 \\
\hline Carcass yield, $\%$ & +0.33 & +0.10 & +0.24 & +0.04 & 48.80 \\
\hline Carcass boneless meat yield, $\%$ & +0.08 & +0.19 & -0.09 & +0.07 & 85.09 \\
\hline Carcass muscle yield, $\%$ & -0.60 & +0.15 & -0.24 & +0.32 & 81.45 \\
\hline \multicolumn{6}{|l|}{ iii. Live body measurement } \\
\hline Marketing body weight, gm & +78 & +52 & +48 & +33 & 1895 \\
\hline
\end{tabular}

Selection based on the full index is expected to develop rabbits having higher body fat weight $(+4.9 \mathrm{gm})$ and favourable body fat partition $(+2.40$ unit $\%$ increase in percentage total body fat depositing as carcass fat). This genetic gain in the total merit is expected to be associated with increases of $78 \mathrm{gm}$ in marketing body weight, 0.33 unit $\%$ in carcass yield, 0.08 unit $\%$ in carcass boneless meat yield and a reduction of 0.60 unit $\%$ in carcass muscle yield. It is, however, possible through use of the restricted full index $\left(\mathrm{I}_{1(\mathrm{TBF})}\right)$ to obtain comparable improvement in body fat partition with lower reduction in carcass muscle yield $(-0.24$ unit \%) at the cost of genetic change in carcass boneless meat yield from gain (+0.08 unit \%) to loss $(-0.09$ unit \%) and reduction in genetic improvement of $30 \mathrm{gm}$ in marketing body weight and 0.07 unit $\%$ in carcass yield.

Selection on the best reduced index $\left(\mathrm{I}_{7}\right)$ is expected to develop rabbits with advantageous fat partition in terms of higher percentage total body fat depositing subcutaneously (+0.35 unit \%), intermuscularly (+1.91 unit \%) and intramuscularly (as 
reflected by +0.15 unit $\%$ increase in carcass muscle yield). As compared with its unrestricted form, the best reduced index without changing total body fatness $\left(\mathrm{I}_{7(\mathrm{TBF})}\right)$ would result in drastic decline in percentage total body fat depositing as kidney knob and channel fat $(+0.37$ vs. -0.18 unit \%) with slight amelioration in that accumulating in the other depots. Selection on $\mathrm{I}_{7(\mathrm{TBF})}$ instead of $\mathrm{I}_{7}$ would reduce improvement in marketing body weight ( +52 vs. $33 \mathrm{gm})$, carcass yield $(0.10$ vs. 0.04 unit $\%)$, carcass boneless meat yield ( +0.19 vs. 0.07 unit $\%)$ and would increase gain in carcass muscle yield ( +0.15 vs. 0.32 unit $\%)$.

It could be concluded that in case of sub-optimal level of body fatness the use of body weight $(\mathrm{BW})$ and heart girth (HG) taken at marketing as sources of information in the selection index

$$
\mathrm{I}_{7}=0.009 \mathrm{BW}-0.988 \mathrm{HG} ;\left(\mathrm{r}_{\mathrm{TI}}=0.561\right)
$$

would be recommended to optimize selection for the given aggregate genotype, and its restricted form:

$$
I_{7(\mathrm{TBF})}=0.009 \mathrm{BW}-1.058 \mathrm{HG} ;\left(\mathrm{r}_{\mathrm{TI}}=0.558\right)
$$

would be advised in case of populations reaching optimal body fatness.

\section{References}

ABDALLAH, O.Y.; SHAHIN, K.A.; LATIF, M.G.A.:

The partition of fat between depots and its distribution in the carcasses of water buffalo and Dutch Friesian cross-bred cattle. Journal of Agriculture Science, Cambridge 98 (1982), 571-786

BUTLER-HOGG, B.W.; WOOD, J.D.:

The partition of body fat in British Friesian and Jersey steers. Animal Production 35 (1982), 253-262

CARREGAL, R.D.; SOLAZZO, A.V.; FERRAZ, J.B.S.:

Production and reproductive performance of New Zealand White rabbits in the tropics. (In Portuguese). Animal Breeding Abstracts 49 (1981), 6598

CHEVALET, C.:

Estimation of phenotypic variance component for an inbred population. II. Application. Annales de Genetique et de Selection Animale, 8(1976), 207-232

CUNNINGHAM, E.P.; MOEN, R.A.; GJEDREM, T.:

Restriction of selection indexes. Biometrics 26 (1970), 67-74

EL-AMIN, F.M.:

A selection experiments for improvement of weight gains and feed conversion efficiency in rabbit. Ph.D. Diss., Bristol University, England.,1974

GEBRIEL, M.G.; SOLTAN, E.M.; YAMANI, K.A.O.:

Early prediction of heavy body weight and good carcass traits in rabbits. Egyptian Poultry Science 9 (1989), 193-204

GRIFFITHS, L.; LESSON, S.; SUMMERS, J.D.:

Studies on abdominal fat with four commercial strains of male broiler chicken. Poultry Science $\mathbf{5 7}$ (1978), $1198-1203$

HARVEY, W.R.

LSMLMW Mixed Least Squares and Maximum Likelihood Computer Program PC-2 Version. Dairy JONES, S.D.M.:

The accumulation and distribution of fat in ewe and ram lambs. Canadian Journal of Animal Science 62 (1982), 381-386

JONES, S.D.M.; RICHMOND, R.J.; PRICE, M.A.; BERG, R.B.:

Effects of breed and sex on the patterns of fat deposition and distribution in swine. Canadian Journal of Animal Science 60 (1980), 223-230

KEMPSTER, A.J.:

Fat partition and distribution in cattle, sheep and pigs. Meat Science 5 (1980), 83-98 
KEMPSTER, A.J.; CUTHBERTSON, A. AND HARRINGTON, G.:

Fat distribution in steer carcasses of different breeds and crosses. I. Distribution between depots. Animal Production, 23 (1976), 25-34.

KROGMEIER, D., DZAPO, V.; MAO, I.L.:

Additive genetic and maternal effects on postweaning growth and carcass traits in rabbits, Journal of Animal Breeding and Genetics 111 (1994), 289-297.

LUKEFAHR, S.D.; OZIMBA, C.E.:

Prediction of carcass merit from live body measurements in rabbits of four breed-type. Livestock Production Science 29 (1991) 323-334

MAHAJAN, J.M.; LAHIRI, S.S.:

Inheritance of broiler traits in New Zealand White rabbits. Indian Journal of Animal Science 51 (1983), 1365-1367

MERKLEY, J.W.;WEINLAND, B.T.; MALONE, G.W.; CHALOUPKA, G.W.:

Evaluation of five commercial broiler crosses. II. Eviscerated yield and component parts. Poultry Science 59 (1980), 1755-1760

MERKUSHIN, V.V.:

Experience with Californian rabbits. (In Russian). Animal Breeding Abstracts 48 (1980), 4968

NIEDZWIADEK, S.:

The evaluation of slaughter value and its application in the selection of rabbits. Krakow, Inst. Zoot., Poland 1978, 48 pp.

OUHAYOUN, J.; ROUVIER, R.; VALIN, C.; LACOURT, A.:

Study of genetic variation of rabbit muscle $\mathrm{PH}$ measured after slaughter. $1^{\text {st }}$ French Conference on Rabbit and Poultry Research, December 1973 , France

SHAHIN, K.A.; ABDALLAH, O.Y.; SHEMEIS, A.R.:

Genetic influences on growth and partition of fat between depots and its distribution in fowl carcasses. Reproduction, Nutrition et Development 30 (1990), 673-681

SHAHIN, K.A.; BERG, R.T.:

Fat growth and partitioning among the depots in double muscled and normal cattle. Canadian Journal of Animal Science 65 (1985), 295-306

SHEMEIS, A.R.; ABDALLAH, O.Y.:

Selection indexes for increased marketing body weight and advantageous body composition in New Zealand White rabbits. Arch. Tierz., Dummerstorf 41 (1998), 11-19

TRUSCOTT, T.G., LANG, C.P.; TULLOH, N.M.:

A comparison of body composition and tissue distribution of Friesian and Angus steers. Journal of Agriculture Science, Cambridge 87 (1976), 1-14

Received: 1998-11-30

Accepted: $2000-01-18$

Authors address

Dr. AHMED R. SHEMEIS, Prof, Dr. OMAR Y. ABDALLAH

Animal Breeding Section, Department of Animal Production, Faculty of Agriculture

Ain Shams University

Shoubra Al-Kheima

11241 Cairo

Egypt 


\title{
35. Kulmbacher Woche
}

\author{
08. bis 10. Mai 2000 \\ Stadthalle Kulmbach \\ Veranstalter: Bundesanstalt für Fleischforschung
}

In der Zeit vom 08. bis 10. Mai 2000 (Beginn $10.00 \mathrm{Uhr}$, Stadthalle Kulmbach) findet die nunmehr „35. Kulmbacher Woche“ statt. Das aktuelle Programm sieht Vorträge und Poster u.a. zu gesunder Ernährung, den Anforderungen an die Fleischwirtschaft im neuen Jahrtausend, qualitätsorientierter und -gerechter Rinder- und Schweineproduktion, Markenfleischprogrammen, Tierschutz und Schlachtung, speziellen Fragen der Fleischverarbeitung und zu Inhaltsstoffen von Fleischerzeugnissen vor. Neben einem Lebensmittelrechtlichen Kolloquium wird auch über spezielle Fragen der Fleischanalytik berichtet.

Die Anmeldung erfolgt bis zum 14.04.2000 an: Bundesanstalt für Fleischforschung

E.-C.-Baumann-Straße 20

95326 Kulmbach

Tel: 09221/803 269 Fax: 09221/803 244 e-mail: baff@compuserve.com

\section{Wilhelm-Stahl-Symposium am 16. und 17. Mai 2000 in Rostock}

Veranstalter:

- Institut für Tierproduktion Dummerstorf der Landesforschungsanstalt für Landwirtschaft und Fischerei Mecklenburg-Vorpommern

- Forschungsinstitut für die Biologie landwirtschaftlicher Nutztiere Dummerstorf

- Agrar- und Umweltwissenschaftliche Fakultät der Universität Rostock

- Landwirtschaftlich-Gärtnerische Fakultät der Humboldt-Universität zu Berlin

Unter der Thematik: „Effiziente tierische Leistung in Verbindung mit einer nachhaltigen Produktion" findet am 16. und 17. Mai 2000 im Hörsaal der Agrar- und Umweltwissenschaftlichen Fakultät der Universität Rostock, Justus-von-Liebig-Weg, Rostock, das nunmehr 3. Wilhelm-Stahl-Symposium statt.

Tagungsschwerpunkte sind:

- Agrarpolitische, ökonomische, ökologische und verbraucherorientierte Aspekte

- Züchtung, Fütterung und Haltung der Hochleistungskuh

- Zukunftsfähige Schweineproduktion

- Fleischproduktion mit Rind, Schaf und Geflügel

Organisationsbüro:

Institut für Tierproduktion Dummerstorf der

Landesforschungsanstalt für Landwirtschaft und Fischerei M-V

Dr. Winfried Matthes

Wilhelm-Stahl-Allee 2

18196 Dummerstorf

Tel: 038208/63031 oder 63010 (Sekretariat) Fax: 038208/63011 e-mail: Ifamv.ift@t-online.de 